\title{
One counter and your own account: redefining illicit labour in early modern Antwerp
}

\author{
BERT DE MUNCK* \\ Centre for Urban History, University of Antwerp, FLW-FDGES, S.D.310, \\ Grote Kauwenberg 18, 2000 Antwerpen, Belgium
}

\begin{abstract}
This article examines the problem of illicit labour from the perspective of transformations in the (local) distribution channels. Rather than large masters circumventing the guilds' rules regarding labour market entry or large merchants shifting from a Kauf to a Verlag system, early modern manufacturing guilds in Antwerp confronted mercers and wholesalers who entered into production without being masters. In response, the guilds extended their rules, so that their regulations actually matured in the course of the sixteenth and seventeenth centuries. Rather than (labour market) deregulation and proto-industrialization, the issue was the disappearance of the straightforward link between production and retailing, tied together by mastership.
\end{abstract}

Traditional historiography on guilds has sketched a dichotomy between the regulated world of 'corporatism' and the unregulated world of free trade and the 'invisible hand'. Entrance to a trade was regulated via apprenticeship, completion of master pieces and financial barriers to entry, and these led to a clear distinction between those 'inside' and those not. ${ }^{1}$ Journeymen had completed apprenticeships, masters had first worked as journeymen. In recent decades historical scholarship has qualified the impact of the guilds' regulations and self-defined boundaries. From an economic perspective, it has been argued that craft guilds did not have a monopoly in the modern sense of the term. ${ }^{2}$ Guilds were not the sole sellers of products in a particular industry, nor did they hinder competition in export markets. Guild officials could only prevent artisans from making the

\footnotetext{
* Thanks are due to the participants at the conference Gruppenbildung - Konfliktaustrag Integrationsstrategien: Neue Perspektiven der Zunftforschung, Konstanz, 12-14 Jun. 2008, for their comments on a first draft of this article.

${ }^{1}$ For recent status questionis and extensive references, see J.R. Farr, Artisans in Europe, 1300 1914 (Cambridge, 2000); H.-G. Haupt (ed.), Das Ende der Zünfte. Ein europäischer Vergleich (Göttingen, 2002); C. Lis, J. Lucassen, M. Prak and H. Soly (eds.), Guilds in the Early Modern Low Countries. Work, Power and Representation (London, 2006).

${ }^{2}$ G. Richardson, 'A tale of two theories: monopolies and craft guilds in medieval England and modern imagination', Journal of the History of Economic Thought, 23, 2 (2001), 217-42; and idem, 'Guilds, laws, and markets for manufactured merchandise in late medieval England', Explorations in Economic History, 41 (2004), 1-25.
} 
same or similar products inside the same city. In order to compete against similar products coming from outside the city (from the countryside or other urban centres) they had to sell imperfect substitutes and invest in brand loyalty. ${ }^{3}$

From the perspective of labour relations, the dichotomy between the regulated world of the guilds and the unregulated world of the 'outside' has also been revised. Historians studying the notorious faubourg SaintAntoine in Paris have pointed to the interconnections between the formal economy intra muros and the informal economy on the outside. City-based masters could employ or subcontract to faux ouvriers in the faubourg; they could even work as subcontractors for, or in company with, an illegal entrepreneur. ${ }^{4}$ Others have pointed to concentration trends and proto-industrialization even within city walls. Subcontracting was tacitly allowed so that masters could employ other masters (including masters from other trades) at their discretion, and masters could work in Kauf or Verlag systems of merchants. ${ }^{5}$ This of course complicates the question of illicit labour. Exactly who in this context was legal or illegal? This question, despite the 'return of the guilds' to the historical agenda, remains largely unanswered.

Most historians connect illicit labour to false work at low wages. The artisans involved are termed chambrellans (in French) or Böhnhase and Störer (in German), alluding to a world of unskilled workers 'without rank' ('sans état') who make their produce surreptitiously (for instance at the back of the house) ${ }^{6}$ Intuitively, clandestine work is related to a type of 'guild decay', particularly erosion from below, of the guilds' rules. ${ }^{7}$ In particular, guilds are seen as being 'flooded by the market', to

${ }^{3}$ E.g., J. Munro, 'Industrial protectionism in medieval Flanders: urban or national?', in H.A. Miskimin, D. Herlihy and A.L. Udovitch (eds.), The Medieval City (New Haven, 1977), 22967; and idem, 'Urban regulation and monopolistic competition in the textile industries of the late-medieval low countries', in E. Aerts and J. Munro (eds.), Textiles of the Low Countries in European Economic History (Louvain, 1990), 41-50.

4 S.L. Kaplan, 'Les corporations, les "faux-ouvriers" et le faubourg St. Antoine au XVIIIe siècle', Annales. ESC (Mar.-Apr. 1988), 353-78; A. Thillay, Le faubourg Saint-Antoine et ses 'faux ouvriers'. La liberté du travail à Paris aux XVIIe et XVIIIe siècles (Paris, 2002).

${ }^{5}$ M. Sonenscher, Work and Wages. Natural Law, Politics and the Eighteenth-Century French Trades (Cambridge, 1989), 130-48; C. Lis and H. Soly, 'Different paths of development. Capitalism in the Northern and Southern Netherlands during the middle ages and the early modern period', Review, 20 (1997), 211-42; idem, 'Export industries, craft guilds and capitalist trajectories', in Lis et al. (eds.), Guilds, 107-32.

${ }^{6}$ See Farr, Artisans, 43 and 285; P.R. Hoffmann, 'Winkelarbeiter, Nahrungsdiebe und rechte Amtsmeister. Die "Bönhaserei" als Forschungsproblem der vorindustriellen Gewerbegeschichte und deren Bedeutung für das frühneuzeitliche Handwerk am Beispiel Lübecks', in C. Jeggle and M. Häberlein (eds.), Vorindustrielles Gewerbe. Handwerkliche Produktion und Arbeitsbeziehungen in Mittelalter und früher Neuzeit (Konstanz, 2004), 183210; idem, 'In defence of corporate liberties: early modern guilds and the problem of illicit artisan work', Urban History, 34 (2007), 76-88.

7 J. Ehmer, 'Traditionelles Denken und neue Fragestellungen zur Geschichte von Handwerk und Zunft', in F. Lenger (ed.), Handwerk, Hausindustrie und die Historische Schule der Nationalökonomie. Wissenschafts- und gewerbegeschichtliche Perspektiven (Bielefeld, 1998), 1977, 65-73, esp. 66. 
paraphrase a metaphor of Steven Kaplan's. ${ }^{8}$ The guilds' eventual demise is typically linked to the removal of the guilds' barriers to labour market entry and to the emergence of industries in the countryside (which was connected to proletarianization and proto-industrialization). ${ }^{9}$ However, this is only one side of the coin, for these moonlighters must have been producing for either large entrepreneurs or merchants. How were the guilds' boundaries blurred from this perspective? Regarding the Southern Netherlands, Catharina Lis and Hugo Soly have related the emergence of industrial capitalism to the initiatives of large masters, who not only employed more workers but also subcontracted to other masters; but at least in part this seems to have happened legally (as was subcontracting among masters). ${ }^{10}$ In some sectors, it might have been merchants who engaged in production by employing licit or illicit workers instead of purchasing the finished product from masters. ${ }^{11}$ Regarding those workers, the question becomes one of distinguishing between, on the one hand, a master piece worker (perhaps working exclusively for one merchant and being paid in raw material) and, on the other, an illegal employee working (perhaps on his own premises as did a master) for a piece wage. However artificial a boundary this may seem, below we will see that for guild-based masters it was crucial.

The problem is that recent research has tended to focus somewhat one-sidedly on export industries. This bias has obstructed recognition of possible correlations between the undermining of master status and transformations in local distribution channels. Current research on industries working for local markets has highlighted the shift from working 'on order' to producing 'to supply a market' (prêt-à-porter or ready to wear) in the tailoring and shoemaking sectors. Such a shift may have been accompanied by wholesalers and retailers having products made or finished by myriad free and unfree workers. ${ }^{12}$ How were the guilds' boundaries defined from this perspective? I argue that in early modern Antwerp the guilds' rules were not gradually eroded or relaxed. Rather, they materialized and developed further in the early

8 Thanks to the guilds 'la communauté n'est pas complètement débordée par ce que nous appelons le marché'. S.L. Kaplan, 'L'apprentissage au XVIIIe siècle: le cas de Paris', Revue d'histoire moderne et contemporaine, 40, 3 (1993), 436-79, at 436.

9 R.S. Duplessis, Transitions to Capitalism in Early Modern Europe (Cambridge, 1997), 35-6, $110,113,118,120-1,126-8,225$. Also Farr, Artisans, 276-97.

10 See n. 5; also C. Lis and H. Soly, 'Subcontracting in guild-based export trades, thirteentheighteenth centuries', in S.R. Epstein and M. Prak (eds.), Guilds, Innovation, and the European Economy, 1400-1800 (Cambridge, 2008), 81-113.

11 E.g., A.K.L. Thijs, De zijdenijverheid te Antwerpen in de zeventiende eeuw (Brussels,1969), 7983; and idem, Van 'werkwinkel' tot 'fabriek'. De textielnijverheid te Antwerpen (einde 15de-begin 19de eеuw) (Brussels, 1987), 236-43.

12 Cf. H. Deceulaer, Pluriforme patronen en een verschillende snit. Sociaal-economische, institutionele en culturele transformaties in de kledingsector in Antwerpen, Brussel en Gent, 1585-1800 (Amsterdam, 2001), 155; G. Riello, A Foot in the Past. Consumers, Producers, and Footwear in the Long Eighteenth Century (Oxford, 2006), esp. ch. 4. Also I. Van Damme, Verleiden en verkopen. Antwerpse kleinhandelaars en hun klanten in tijden van crisis (ca. 1648-ca. 1748) (Antwerp, 2007), 237. 
modern period, particularly in response to the clandestine activities of wholesalers and retailers. In the first section, we will see that standard ideas about deregulation of the labour market (e.g., workshop size gradually increasing in the context of emerging industrial capitalism and subcontracting among masters) should be complemented. While limits to workshop size tended to be relaxed from the sixteenth century on, other regulations - typically those defining master status - were strictly enforced and further developed. In the second section, attention shifts to the product market. It will be shown that guild officials were not principally concerned about possible proletarianization of masters or about the shift from a Kauf to a Verlag system. Rather, they were concerned about the connection between product quality and master status. In the third and final section the gradual demise of the guild system is reconsidered from the perspective of the so-called 'retail (r)evolution'. The general thesis is that the guilds' main problem was not that some masters grew larger but that mercers intruded into the field of production, thus blurring established differences between the retailing and production sectors.

For sources, I have used the broadest possible sample of guild ordinances. Virtually all craft guilds plus the mercers' guild were included. ${ }^{13}$ Additionally, an in-depth study of judicial litigations in a sample of guilds (the cabinet makers, the carpenters, the diamond cutters and gold and silversmiths, the pewterers and plumbers and the shoemakers and tanners) was analysed. ${ }^{14}$ To compensate for the bias towards export industries found in most research and so as to concentrate on the changing relationship between producing and retailing, I have deliberately chosen crafts that were at least partially active on the local (and regional) market. ${ }^{15}$

\section{Distinguishing faux ouvriers from faux maîtres}

Most literature on guilds and the problem of unfree labour does not clearly distinguish between unfree or un-privileged employees (faux ouvriers) and

13 Totalling about 30 guilds and some 50 ordinances.

14 Some of these sources were collected during my Ph.D. research on apprenticeship in Antwerp guilds. See B. De Munck, Technologies of Learning. Apprenticeship in Antwerp from the Fifteenth Century to the End of the Ancien Régime (Turnhout, 2007).

15 In 1738 my sample of guilds contained only $16.2 \%$ of the total number of masters at that time (511 out of 3,150 masters (mercers excluded), see F. Smekens, Verzamelde geschriften (Borgerhout, n.d.), 62-7 (Bijlage II. Ambachten. Toestand in 1738)), but the two most important industries in numerical terms (textiles and tailoring) were included via existing literature, especially Thijs, Van 'werkwinkel' tot 'fabriek', and Deceulaer, Pluriforme patronen. Moreover, in most of the juridical proceedings craft guilds confronted individual mercers or the mercers' guild, being the most important group of all in numerical terms $(1,500$ to 2,500 members, see B. Blondé and H. Greefs, 'Werk aan de winkel: de Antwerpse meerseniers: aspecten van kleinhandel en verbruik in de $17 \mathrm{de}$ en $18 \mathrm{de}$ eeuw', in De lokroep van het bedrijf: handelaars, ondernemers en hun samenleving van de zestiende tot de twintigste eeuw. Liber amicorum Roland Baetens (Antwerp, 2001) (Bijdragen tot de geschiedenis, 84:1-3), 211-13). 
unfree or un-privileged employers (faux maîtres). For a clear insight, we should distinguish illicit 'journeymen' from illicit 'masters'. Employees could be illegal when, for example, they exceeded the maximum numbers of journeymen or apprentices per master. In some guilds there was, moreover, a distinction between 'free' and 'unfree' journeymen so that journeymen, in order to be allowed to work in a master's workshop, had to complete an apprenticeship term and a master piece. The privilege of the so-called free journeymen ('vrije gezellen') consisted of a 'right of preference', which prevented masters from hiring outsiders ('onvrije gezellen'), i.e., journeymen who had not finished an apprenticeship term (or a master piece) ${ }^{16}$ To understand the rationale behind this, we should approach it from the perspective of journeymen. The right of preference forced masters to favour free journeymen when recruiting workers. Masters were allowed to recruit unfree journeymen only when no free journeymen were available or willing to work. ${ }^{17}$ Not coincidentally, this right of preference was accompanied by a minimum wage, which masters tried to circumvent when hiring unfree journeymen (who had not finished an apprenticeship term). Similarly, the right of preference often included the obligation that the journeyman make a trial piece. This suggests that the practice of the 'journeyman piece' was established at the instigation of journeymen and with the aim of clearly distinguishing between 'free' and 'unfree' journeymen. A journeymen's trial, after all, only occurred in crafts with a right of preference. ${ }^{18}$ As this right typically existed in industries with large numbers of journeymen, it is easy to imagine that their numerical strength enabled them to enforce the practice.

Remarkably, however, the distinction between free journeymen and unfree journeymen was not always present. ${ }^{19}$ Gold and silversmiths, in their founding ordinance in 1454, prescribed an apprenticeship term, but article 2 explicitly states 'that all good alien journeymen, wherever they come from, who want to earn their living in Antwerp, with a master for a daily wage, by contract or by piece, should be allowed to do so without

${ }^{16}$ For Antwerp, see Thijs, Van 'werkwinkel' tot 'fabriek, 372-3, 398-9 (cloth dressers, fullers and yarn twisters); Deceulaer, Pluriforme patronen, 294 (hosiery makers); C. Lis and H. Soly, 'De macht van "vrije arbeiders": collectieve acties van hoedenmakersgezellen in de Zuidelijke Nederlanden (zestiende-negentiende eeuw)', in C. Lis and H. Soly (eds.), Werken volgens de regels. Ambachten in Brabant en Vlaanderen, 1500-1800 (Brussels, 1994), 15-50 (hat makers); and B. De Munck, 'Meritocraten aan het werk. Deregulering van de arbeidsmarkt bij de Antwerpse timmerlieden in de 18de eeuw', in B. Blondé, B. De Munck and F. Vermeylen (eds.), Doodgewoon. Mensen en hun dagelijks leven in de geschiedenis. Liber Amicorum Alfons K.L. Thijs (Antwerp, 2005), 87-106 (carpenters and masons).

17 E.g., City Archives Antwerp (hereafter CAA), Guilds and Crafts (hereafter GC) 4267, 27 Jun. 1718, fols. 68-9; GC 4267, 23 Aug. 1754 (extract), arts. 12, 16 and 17 (masons); GC 4028, 7 Oct. 1536, fols. 17-18 (cloth dressers).

18 A separate trial piece for journeymen has been documented for Antwerp, with the cloth dressers, the masons and the carpenters. E. Scholliers, 'Vrije en onvrije arbeiders, voornamelijk te Antwerpen in de 16de eeuw', Bijdragen voor de geschiedenis der Nederlanden, 11 (1956), 285-322, at 288, 291-2; and CAA, GC 4341, 31 Mar. 1543, arts. 5-6.

19 E.g., Deceulaer, Pluriforme patronen, 284-5. 
further due'. ${ }^{20}$ The diamond cutters had a similar ruling, in that 'every alien journeyman wanting to work here must do so with a free master and when asked have his name written down at the guild chamber within three days' ${ }^{21}$ The shoemakers stipulated that 'no master shall employ an unfree journeyman outside his house nor will journeymen be allowed to work other than in a master workshop', implying that they could work for a regular master. ${ }^{22}$ In other words, these guilds established the obligation to work for a free master, not the obligation to be 'free' for workers. In most guilds there was no reference to distinction between free and unfree journeymen or to possible obligations for journeymen to have finished an apprenticeship term. Thus, apprenticeship should be considered an entry to mastership rather than to journeyman status.

Doubtlessly this has serious consequences for research on social mobility in guilds. Historians have generally assumed that apprentices typically rose from the status of apprentice to that of journeyman and then to mastership, but we must now distinguish between an apprentice who wanted to become a master directly (perhaps after having already worked as an 'unfree' journeymen for years) and apprentices who sought to become a journeyman. ${ }^{23}$ Secondly, and more important for this article, the question of the changing size of the firms should be reframed. What was the relationship between workshop size and the journeymen's right of preference? And how did workshop size evolve in the long term?

The absence of a right of preference did not thwart guilds from limiting workshop size, but in general the traditional narrative of gradual deregulation holds: rules concerning the maximum number of journeymen were typically relaxed, especially in the sixteenth and eighteenth centuries. As the economy expanded, concentration of production in the hands of large masters increased. This shift typically occurred in export industries especially textiles - but even guilds as different as shoemakers and cabinet makers evolved from allowing one 'workbench and one stall' or 'one journeyman and one apprentice' at the end of the fifteenth century to allowing a maximum of six journeymen (in addition to their children) during the sixteenth century. ${ }^{24}$ In the mid-eighteenth century, the conflict between small masters striving to limit the number of employees and large

20 CAA, GC 4488, 24 Feb. 1454, art. 2.

${ }^{21}$ CAA, GC 4002, 25 Oct. 1582, art. 25. If they stayed longer than six months, they had to pay $£ 1$ 10s (art. 26), which was the same as newly registered apprentices (art. 11).

22 CAA, GC 4112, 30 Jan. 1606, fols. 94v-95; GC 4112, 24 Nov. 1603, fols. 86v-87v.

23 Cf. De Munck, Technologies, ch. 4. The practice of forsaking future mastership in return for a lower registration fee for apprentices seems to have been rare in the Southern Netherlands. One exception in CAA, GC 4487, account book gold and silversmiths, fol. 35 (account 156465).

24 CAA, GC 4112, 3 Dec. 1477, fols. 39r-43v, arts. 16 and 33; GC 4112bis, p. 50 (copy); GC 4112, 24 Nov. 1603, fols. 86v-87v; GC 4112, 30 Jan. 1606, fols. 94v-95r (shoemakers); GC 4334, fols. 1ff; GC 4335, 14 Jun. 1497, fol. 2v; GC 4334, fol. 22; GC 4335, 24 Dec. 1519, fols. 26vff; GC 4334, fol. 22v, GC 4335, 4 Jun. 1522; GC 4334, fols. 71r-72v; GC 4335, 25 Mar. 1621, fols. 92v-94r (cabinet makers). 
masters wishing to deregulate the labour market seems to have turned in favour of the latter, suggesting that industrial capitalism came about as large masters prevailed and succeeded in concentrating production in their own hands. ${ }^{25}$

These findings correspond to Lis and Soly's thesis that the large entrepreneurs in the industrial sectors of Flanders and Brabant came from the ranks of the craftsmen rather than the merchants. ${ }^{26}$ In some sectors with a right of preference for journeymen, guilds adopted strategies to include unfree workers, most likely at the instigation of large masters. From the fifteenth and sixteenth centuries on, guild-based masters could often, within certain limits (mostly for a specific period of time), employ unfree journeymen when confronted with production peaks. ${ }^{27}$ The guilds of the carpenters and the masons (the Vier gekroonden) legalized unfree journeymen in the eighteenth century by establishing a bankgeld, a small tax related to how many days an unfree journeyman worked (typically one stuyver per day)..$^{28}$

At the level of the employers or masters, however, there was an opposite trend. Here regulations tended to become stricter, or at least more elaborate. At first glance the distinction between masters and illegal employers may seem far more straightforward than the distinction between free and unfree journeymen from the start. Anyone who finished an apprenticeship term, completed a master piece (if required) and paid the entry fees could call himself a master. On the face of it, moreover, it was clear what masters could and could not do. They could make all products on which the guilds had a monopoly, and have their apprentices and journeymen make the products. However, things become more complicated if we concentrate on labour relations at large. Prohibitions on subcontracting were usually absent, and this allowed masters to have their products made by other masters (regardless of the latter's trade) or to make them (or have them made) for other masters. Masters could even be explicitly permitted to have products made by non-masters outside their workshop. ${ }^{29}$ Nonetheless, guilds and guild officials continued to distinguish between masters and illegal entrepreneurs, and even devised new instruments for doing so. The question is why?

As we will see below, the guilds in our sample typically faced the problem of legal masters working directly for an illegal entrepreneur, not as

${ }^{25}$ See, e.g., Thijs, Van 'werkwinkel' tot 'fabriek', 219-57; Deceulaer, Pluriforme patronen, 162-3; De Munck, 'Meritocraten'.

26 See n. 10.

27 They had to pay a certain income fee or recurrent tax then. E.g., F. Prims, 'Het kleermakersambacht', Antwerpiensia, 10 (1936), 357-8 (tailors); CAA, GC 4017, n.d., art. 7 (fullers); GC 4267, 21 Aug. 1458, fol. 4 (masons); GC 4341, 31 Mar. 1544, arts. 13-14 (carpenters).

28 CAA, GC 4267, 22 Mar. 1725, fol. 70 (masons); GC, 4345, 23 Feb. 1767, fol. 83, art. 1; GC 4343, Account 1700-03; GC 4343, Account 1711-12 (carpenters).

${ }^{29}$ CAA, GC 4334, fols. 1ff; GC 4335, 14 Jun. 1497, fol. 2v; GC 4334, fols. 65r-66v; GC 4335, 28 Apr. 1621, fol. 83vff, art. 9; Deceulaer, Pluriforme patronen, 109, 137, 144-5, 300. 
a subcontractor or in a Kauf system (selling all his produce to one or several merchants) but as a type of employee. ${ }^{30}$ Guilds had few options in trying to counter this. In the absence of a master piece and regular workshop visits by guild officials, it was easy for an illegal entrepreneur to become a master. He simply registered as an apprentice with a free master, in return for financial or other compensation to the master in question. ${ }^{31}$ Once the term prescribed by the guilds had expired, such an entrepreneur could become a master simply by paying the fees due and swearing an oath - even if he had not spent one day on the master's shop floor. One of the guilds' responses was to obligate masters to make a master piece, which they appear to have done in particular in the long sixteenth century. ${ }^{32}$ When this strategy failed - among other things because prospective masters did not always make their trial piece themselves ${ }^{33}$ - guild boards forced apprentices to live on their master's premises, a measure they explicitly attributed to the need to block fictitious apprenticeships. ${ }^{34}$ In response to these measures, faux maitres concluded fictitious apprentice contracts whereby fictious apprentices either moved in with their 'master' (allegedly to learn, while in reality the master worked for them) or the 'master' moved in with them. ${ }^{35}$ The gold and silversmiths considered setting a maximum age so as to prevent adult newcomers interested in settling in Antwerp from having other masters register them as fictitious apprentices to comply with guild regulations. ${ }^{36}$

But guilds still faced the problem of illegal masters using the trademark or the name of a legal master (in exchange for money or because they

30 CAA, GC 4334, 10 Dec. 1543, fols. 23v-24v; GC 4335, fol. 30r-v (cabinet makers); GC 4028, 20 Sep. 1696, p. 123, arts. 7, 8 and 10 (cloth dressers); GC 4341, 19 Dec. 1657 (carpenters).

31 E.g., CAA, GC 4264, 7 Mar. 1543 (1544) (tinsmiths and plumbers); GC, 4262, 7 Sep. 1521, fols. 1-2 (oil pressers); GC 4255, 17 Jan. 1595, arts. 6ff (hat makers).

32 A master piece was first mentioned in 1497 for the cabinet makers, in 1523 for the tinsmiths, in 1524 for the gold and silversmiths, in 1528 for the linen weavers (small weavers and tick weavers in the seventeenth century), in 1543 for the carpenters, in 1583 for the shoemakers and tanners and in 1639 for the twiners. CAA, GC 4334, 14 Jun. 1497, art. 2, fol. 1v; GC 4335, fol. 1 (copy); GC 4264, 12 Nov. 1523; GC 4488, 24 Nov. 1524; GC 4341, 31 Mar. 1543, arts. 5-6; GC 4112, 18 Apr. 1583, fol. 62v; F. Prims, Geschiedenis van Antwerpen, 10 vols. (Antwerp, 1927-49), vol. VII, 2nd book, 48, and VIII, 2nd book, 76; Thijs, Van 'werkwinkel' tot' fabriek', 99. The cloth dressers prescribed a master piece in 1536, although this may have already been defined before. CAA, GC 4029, 7 Oct. 1536, art. 3. Additional trials were prescribed also with the 'Viergekroonden' in 1674 (stone cutters, slaters and road pavers); CAA, GC 4267, 17 Mar. 1674.

33 E.g., CAA, GC 4334, 6 Aug. 1515, fols. 7v-9v; GC 4112bis, 13 Sep. 1774, pp. 192-7, art. 7.

34 CAA, GC, 4262, 7 Sep. 1521, fols. 1-2 (oil pressers); GC 4264, 1 Mar. 1543 (1544); GC 4004, 4 Jul. 1651, fols. 42v-43v (pewterers and plumbers); GC 4488, 24 Jan. 1543, fols. 76r and 78r (gold and silversmiths); GC 4017, 30 May 1576, fols. 333ff (cloth cutters); GC 4255, 17 Jan. 1595, arts. 6ff (hat makers); GC 4028, 20 Sep. 1696, art. 1 (cloth dressers).

35 CAA, Notary's Archives Antwerp (herafter N) 45, fol. 168 (1701); N 1303, fols. 49, 199 (1747); N 4402, fol. 24 (1749); N 2913, 9 Feb. 1752; GC 4490, 6 Mar. 1781. Sometimes they founded a company, typically among family members: CAA, N 2787, fol. 66 (1669); N 764 , fol. 35 (1721).

36 D. Schlugleit, De Antwerpse goud-en zilversmeden in het corporatief stelsel (1382-1789) (Wettern, 1969), 242-8. 
had founded a 'company') in order to legalize their products. ${ }^{37}$ As early as the third quarter of the sixteenth century, some gold and silversmiths founded companies with 'unfree persons who do not live with their master and who are working at a place where the guild sign does not hang out'. Some were found 'in a shop' in the so-called Pand (building) of Our Lady, where they contracted work, in turn, to unfree workers. ${ }^{38}$ Thus, it was generally forbidden for masters to found companies, as such companies would enable them to regulate illegal entrepreneurs (and work for them at the same time). ${ }^{39}$ Similarly, free and unfree journeymen were sometimes allowed to work for a master only if they lived or at least worked directly on his premises. ${ }^{40}$ The reason for this appears to have been that such journeymen often worked on their own accounts, perhaps even employing the master rather than vice versa.

\section{From proletarianization to discussions on product quality}

When viewing the decline of the guilds, historians are accustomed to consider the major underlying factor to have been increasing outside pressure on a long-standing, fully fledged guild system. Yet in Antwerp, the reverse was true. The guild system actually matured in the sixteenth and seventeenth centuries. In the second decade of the seventeenth century, master diamond cutters protested against a Portuguese merchant who had several masters working directly for him. The guild repeatedly reaffirmed its bans on working in company and on 'freeing' unfree workers, but in the course of the eighteenth century the merchants prevailed and became true fabriquateurs. ${ }^{41}$ The ribbon makers' guild legalized the production activities of merchants in 1721. It was stipulated that merchants could become guild members if they paid an income fee (used to fund the

37 I limit myself to some examples here: CAA, GC 4488, fols. 76r and 78r; GC 4485, no. 1, 24 Jan. 1543, fols. 11r-12v; GC 4485, no. 2, 9 Feb. 1557, fol. 13r-v; GC 4001, fols. 187v-188r (gold and silversmiths); GC 4003, 21 Jan. 1621, fol. 26 (silk weavers); GC 4337, 19 Jul. 1694, fol. 36 (cabinet makers); Deceulaer, Pluriforme patronen, 162. See also Thijs, Van 'werkwinkel' tot 'fabriek', 327-35.

38 CAA, GC 4002, 22 Nov. 1574, fols. 64-5; Schlugleit, De Antwerpse goud-en ziversmeden, 74-5, $110-11$.

39 See, e.g., GC 4002, 25 Oct. 1582, arts. 30-4; GC 4477, 9 Nov. 1605, art. 4 (diamond cutters); Schlugleit, De Antwerpse goud-en zilversmeden, 139ff, 242-8; CAA, Process dossiers (hereafter P), A 562, 1651-52; GC 4485, no. 2, 9 Feb. 1557, fol. 13r-v; GC 4002, 22 Nov. 1574, fol. 64v (gold and silversmiths); GC 4264, 1 Mar. 1543 (1544) (pewterers and plumbers); GC 4101, 5 Nov. 1590, fols. 38-40 (wood breakers); GC 4255, 17 Jan. 1595 (hat makers); GC 4042, 3 Aug. 1622, art. 26 (camlet dyers). This is similar to the prohibition for tailors to live in second-hand dealers' or stocking makers' premises. Prims, 'Het kleermakersambacht', $361-2$.

${ }^{40}$ CAA, GC 4028, 7 Oct. 1536, fol. 18 (cloth dressers); GC 4002, 22 Nov. 1574, fol. 65r (gold and silversmiths). See also GC 4485, no. 3, fol. 14v; GC 4112, 24 Nov. 1603, fols. 86v-87v; GC 4112, 30 Jan. 1606, fols. 94v-95r (shoemakers).

${ }^{41}$ D. Schlugleit, Geschiedenis van het Antwerpsche diamantslijpersambacht (Antwerp, 1935), 44-5, 84-5; 145-7. 
poor box) ${ }^{42}$ However, unlike the distinction between free and unfree journeymen, masters were not inclined to loosen the rules concerning master status until at least the end of the seventeenth century. Two of the guilds' most typical regulations - the compulsory master piece and requiring apprentices to live on their master's premises - emerged as attempts to address the problems of entrepreneurs circumventing master status. Even a fixed term of service is likely to have been introduced for that reason. In the first half of the fifteenth century guild officials merely had to declare before the city magistrates who a person was when accepting him as a new member. ${ }^{43}$ At best, new masters were required to 'demonstrate' their competence, which presumably meant that master trials were required ad hoc for prospective masters not known in the city. ${ }^{44}$ From the second half of the century on, an apprenticeship period gradually became obligatory - followed (some decades later) by the installation of master pieces and backed by measures preventing fictitious apprentice contracts and the foundation of companies. The rationale was to define and defend master status. The difference between a 'merchant' illegally acting as a producer and a large 'entrepreneur' legally acting as a master was the obligatory apprenticeship term and master piece for masters.

This answers the question of what the difference was between an employee working for piece wages (perhaps on his own premises and at the same wage as a master's) and one selling his products by the piece to a merchant or a wholesaler (as a regular master, but perhaps being paid in raw material). An interesting judicial conflict between the 'nation' of the pewterers and plumbers (a guild subordinate to the mercers' guild) and several large mercers is revealing in this context. About 1600 some 'mercers' (sometimes called 'potiers' ('potverkoopers')) were accused not of buying and selling pots but of producing them. The problem was that they hired pewterers, whom they paid in cash or with pewter, to make pewter lids that were then attached to earthen pots furnished by the mercers. ${ }^{45}$ The guild of the pewterers and plumbers claimed that the potiers had to be masters to do this, or, in other words, that they had to have finished an apprenticeship term and a master piece. The potiers claimed that they were merely selling pots, and that it was thus sufficient that they belong to the mercers' guild. But the pewterers continued to differ. Indeed, it was allowed for tinsmiths to work exclusively for mercers and to sell lids to them by the dozens. The problem, however, was that the tinsmiths - in

42 Prims, Geschiedenis van Antwerpen, vol. IX, 2nd book, 78.

${ }^{43}$ CAA, GC 4001, 8 Feb. 1404, fol. 3r (shoemakers); GC 4001, 1 Sep. 1421, fol. 17r (shipmasters); GC 4001, 18 Oct. 1424, fol. 39v (wood breakers); GC 4001, 1 Mar. 1434, fol. 12 (blacksmiths); GC 4001, 20 Aug. 1428, fol. 49r (coopers); GC 4001, 6 Nov. 1436, fol. 1r (carpenters); GC 4267, 21 Aug. 1458, art. 2 (masons); GC 4273, 10 Nov. 1436, fol. 30r (second-hand dealers).

44 E.g., CAA, GC 4001, 8 Feb. 1404, fol. 3r (shoemakers); GT 4001, 6 Nov. 1436, fol. 1r, art. 2 (carpenters); GC 4001, 20 Aug. 1428, fol. 49 (cabinet makers and coopers); GC 4352, 1 Mar. 1434, fol. 12v (blacksmiths).

45 CAA, GC, 4265, Duplicque (n.d.), arts. 7-10 and 16. 
not only making the lids but attaching them to the pots - were thus working 'as a servant' ('dienaer') instead of 'as a master... who sells his tin and earns a living in doing that ${ }^{\prime}{ }^{46}$ Significantly, the case of the pewterers was based on an ordinance stating that tinsmiths could make tinwork only on their own account. ${ }^{47}$

Although the number of apprentices and journeymen working for the tinsmiths was mentioned in the judicial proceedings, the conflict revolved around the economic relationship between masters and mercers. In the end, the problem for the guilds was not so much that masters worked as servants or employees, but that some entrepreneurs, who were not masters and thus should not have been allowed to engage in production, were doing so nonetheless. This same problem underscored a conflict between the shoemakers and the tanners: the tanners contested the right of shoemakers to buy hides and have them tanned by the tanners (rather than buying tanned hides directly from them). A compromise was reached in the last decades of the seventeenth century. It stated that shoemakers had the right to buy hides and have them tanned by a tanner, provided the tanner was a master tanner. Conversely, tanners could have shoes made, provided they were made by a master shoemaker. ${ }^{48}$ Here as well, the craft guilds were determined to differentiate between a master working 'on his own account' and a master working as an employee to faux maîtres. Although the distinction between a master piece worker paid in tin and an employee working on his own premises and paid per piece may have seemed trivial, for the masters it was crucial.

The point, however, was not proletarianization of masters as we traditionally understand it. Indeed, in the conflict between the tinsmiths and the mercers, the question was not who possessed the means of production. Nor did these conflicts revolve around the difference between a Kauf and a Verlag system. The fact that the pewterers were sometimes paid in raw material was not seen as a problem. Instead, the issue was that large entrepreneurs who were not masters acted as producers rather than as merchants and that small masters served as employees instead of as subcontractors or as independent piece workers. These two problems should be considered as two sides of one and the same coin. For the craft guilds, the products had to be made (or at least the production process had to supervised) by a master. ${ }^{49}$ In 1652 a master silversmith with eye problems founded a company with his brother-in-law, whom he officially paid only food and board. The guild officials protested, arguing that the brother-in-law had a part in the company's profit, which was forbidden

46 CAA, GC 4265, Duplicque, art. 27.

47 CAA, GC 4265, Duplicque; GC 4002, 25 Aug. 1572, fol. 30v.

48 CAA, GC 4114, Corte instructie ende redenen van scheijdinghe voor. .., n.d., art. 14.

49 See B. De Munck, 'La qualité du corporatisme. Stratégies économiques et symboliques des corporations anversoises du $\mathrm{XV}^{\mathrm{e}}$ siècle à leur abolition', Revue d'histoire moderne et contemporaine, 54, 1 (2007), 116-44. 
as he was not a master. ${ }^{50}$ Had the brother-in-law been able to prove that he received a wage, there would not have been a problem. For the same reason it was sometimes forbidden for masters to work or to open shops outside their own houses. ${ }^{51}$

The ultimate argument of the guild-based masters was always product quality. In their conflict with the potiers, the pewterers argued that the lids were not made according to the standards applied by masters. For the tanners, the ultimate problem was that entrepreneurs integrating tanning and shoemaking could use tanned hides of lesser quality for shoes. ${ }^{52}$ In a notorious judicial litigation from the first half of the seventeenth century between the gold and silversmiths and the mercers, the guild protested against the mercers' habit of putting silver on leather belts. They argued that the mercers were not allowed to act as producers because they might use inferior silver instead of the alloy the guild prescribed..$^{53}$

Of course, the importance of product quality as such does not explain the importance of defining master status. Guilds' apprenticeship arrangements did not necessarily result in skills or products of higher quality. From the evidence of private apprentice contracts, apprentices often appear to have been under tutelage longer than the term the guilds prescribed, ${ }^{54}$ or they learned specialized skills or moved from workshop to workshop to learn a wider range of skills. ${ }^{55}$ As a result, the skills of guildbased artisans were not necessarily superior to the skills of outsiders. In the mid-eighteenth century, masters in the building sector discussing the use of unfree labour with free journeymen claimed that unfree journeymen, some of whom were aliens, were better trained and had skills more attuned to demand. ${ }^{56}$ Moreover, the range of wages within the group of free artisans could show huge differences among 'qualified' artisans, to the extent that differences within the group of free journeymen were greater than the differences between qualified and unqualified journeymen. ${ }^{57}$ By around 1600 unfree journeymen were sometimes paid more than free journeymen, suggesting that they were better trained. ${ }^{58}$

Still, as masters regarded themselves as the ultimate warrantors of product quality, any use of a trade mark by someone who had not finished

50 CAA, P A 562, 1651-52.

51 CAA, GC 4028, 20 Sep. 1696, art. 10 (cloth dressers); GC 4485, 4 Oct. 1688, fols. 33r-v (gold and silversmiths).

52 CAA, GC 4114, 15 Jul. 1697.

53 D. Schlugleit, 'De zilverhandel van de Meerse en de ordonnantiën van de goudsmeden te Antwerpen in de zestiende eeuw', Bijdragen tot de geschiedenis, 30 (1939), 51.

54 Most apprenticeship terms were rather short in Antwerp, and master pieces were not always due. See H. Deceulaer and M. Jacobs, 'Qualities and conventions. Guilds in eighteenth-century Brabant and Flanders: an extended economic perspective', in S.R. Epstein, H.-G. Haupt, C. Poni and H. Soly (eds.), Guilds, economy and society (Seville, 1998), 91-107; and De Munck, Technologies, ch. 1.2 and 2.2.

55 De Munck, Technologies, ch. 1.

56 CAA, GC 4345, 31 Aug. 1761, fols. 57ff; GC 4345, 22 Oct. 1770, fol. 106.

57 This is based on data from the mid-eighteenth century; see De Munck, 'Meritocraten'.

58 CAA, GC 4001, fol. 53, copy in GC 4030, fol. 53r-v. 
an apprenticeship term and master piece - either by having the mark lent to him in exchange for money or because he worked in company with a legal master - was the ultimate offence. This is why, as a rule, only masters (about half the workforce at best) were required to make a master piece.

The reasons craft guilds were unable to safeguard master status are found in the product market rather than the labour market. Ultimately, the conflicts between the potiers and the pewterers and between the gold and silversmiths and the mercers were about products that crossed guild boundaries, e.g., earthenware with tin lids or leather belts with silver buckles. Similar problems surfaced in the production of luxury furniture. Luxury cabinets (cantoren, scribaenen and the like) were renowned for the myriad raw materials and skills used in making them; besides exotic timbers, these included silver, ivory, tortoiseshell, agate and lace. This was one of the sectors in which important art-dealers were accused of transgressing the thin line between trade and production. During the seventeenth century, art dealers (including Guilliam Forchondt) were accused of acting as large producer-entrepreneurs without being masters or being able to perform the job themselves. ${ }^{59}$

For sure, guilds had faced these problems for decades, but from the seventeenth century onward their arguments seem to have lost credibility. As I have shown elsewhere, beginning in the sixteenth century increasing product complexity and changing consumer preferences forced masters and merchants alike to adopt strategies aimed at reducing information asymmetries (i.e., the seller of a product having more or better information on product quality than the buyers, resulting in a lack of trust among the latter). The guilds adhered to their system of quality controls and trademarks, diversifying their marks as the product range increased. Merchants seem to have welcomed this initially, but as consumer preferences shifted towards less expensive and more fashionable products in the seventeenth and eighteenth centuries ${ }^{60}$ the guilds' arguments, based upon product quality and masters' trustworthiness, became harder to sustain. Merchants and mercers progressively competed with low prices instead of high quality, and invested in novelty and design rather than

${ }^{59}$ Cf. R. Fabri, De 17de-eeuwse Antwerpse kunstkast. Typologische en historische aspecten (Brussels, 1991), 115, 137ff.

${ }^{60}$ Deceulaer, Pluriforme patronen, ch. 5; B. Blondé, 'Tableware and changing consumer patterns: dynamics of material culture in Antwerp, seventeenth-eighteenth centuries', in J. Veeckman (ed.), Majolica and glass from Italy to Antwerp and Beyond: The Transfer of Technology in the Sixteenth - Early Seventeenth Century (Antwerp, 2002), 295-311; I. Van Damme, 'Changing consumer preferences and evolutions in retailing: buying and selling consumer durables in Antwerp (c. 1648-c. 1748)', in B. Blondé, P. Stabel, J. Stobart and I. Van Damme (eds.), Buyers and Sellers. Retail Circuits and Practices in Medieval and Early Modern Europe (Turnhout, 2006), 199-223; B. Blondé and I. Van Damme, 'Een crisis als uitdaging? Kleinhandelsevoluties en verbruiksveranderingen te Antwerpen (ca. 1648 - ca. 1748)', Tijdschrift voor sociale en economische geschiedenis, 4, 1 (2007), 61-88, esp. 66-76. 
brand loyalty. ${ }^{61}$ In this context merchants and mercers encroached on the masters' terrain, whereas guilds devised strategies (master pieces, boarding requirements for apprentices, etc.) to prevent them from doing so.

\section{From an industrial to a retail revolution}

Theoretically, of course, there would not necessarily have been conflict between merchants (or mercers) and masters over product quality. Both masters and merchants (or mercers) had an interest in reducing information asymmetries. Indeed, it is often difficult to distinguish between merchants or mercers who were delegating monitoring costs for guarding product quality to the guild and craft guilds referring to product quality in order to distinguish masters from faux-maîtres. The founding ordinances of new craft guilds established in the sixteenth century that relate deliberations preceding the establishment of the guild in question suggest that merchants and (some) masters had agreed on the necessity to erect a guild and issue rules. ${ }^{62}$ Yet, in the seventeenth and eighteenth centuries tensions between masters and merchants (and mercers) appear to have increased.

On a cultural level, this might have been due to changing consumer preferences and concomitant 'repertoires of evaluation'. Craft guilds, while establishing rules for product quality, inevitably objectified product quality. ${ }^{63}$ By establishing a distinction between 'qualified' and 'unqualified' products, they defined what quality was. Their 'justification' of quality was based largely on the quality of the raw material used. Trademarks typically referred to the quality of the wood used by cabinet makers, the quality of the tanned hides used by shoemakers and the alloy of tin and silverware used by pewterers, plumbers and gold and silversmiths. Within the same industry, trademarks tended to distinguish among the different sorts of raw materials used. The shoemakers' trademarks, for example, distinguished between different parts of the hide, such as the parts of the animal skin that could be used for new shoes and those that could be used only to repair shoes or to make children's shoes. ${ }^{64}$ The trademarks used by cabinet makers referred to the quality of the wood

${ }^{61}$ Cf. B. De Munck, 'Skills, trust and changing consumer preferences. The decline of Antwerp's craft guilds from the perspective of the product market, ca. 1500 - ca. 1800', International Review of Social History, 53 (2008), 197-233.

62 CAA, GC 4002, 25 Oct. 1582, fols. 202-9, art. 15; GC 4001, 5 Nov. 1556, fols. $186 \mathrm{v}-187$ (ribbon makers).

63 Cf. F. Eymard-Duvernay, 'Conventions de qualité et formes de coordination', Revue économique, 40 (1989), 329-59; idem, 'Coordination des échanges par l'entreprise et qualité des biens', in A. Orléan, Analyse économique des conventions (Paris, 1994), 331-58; M. Callon, C. Méadel and V. Rabeharisoa, 'The economy of qualities', Economy and Society, 31 (2002), 194-217. Also Ph. Minard, 'Les corporations en France aux XVIIIe siècle: métiers et institutions', in S.L. Kaplan and Ph. Minard (eds.), La France, malade du corporatisme? XVIIle-XXe siècles (Paris, 2004), 39-51.

64 E.g.. CAA, GC 4112, 3 May 1593, fols. 74r-75r; GC 4112bis, pp. 86-8 (copy). 
used or to indicate that the right wood had been used (for example, genuine ebony wood rather than Spanish wood, which had a similar appearance). The pewterers and plumbers and the gold and silversmiths had different marks for different alloys and according to the quality and the amount of tin and silver in the alloy. ${ }^{65}$ In all these industries product quality was objectified by reducing it to an invisible feature of the product not coincidentally, of course, the most expensive feature.

From this perspective, it is easy to imagine why the guilds' claims lost credibility in the face of changing consumer preferences (stressing novelty and design). But how was this reflected in the local distribution channels? In the discussions between guilds and illicit entrepreneurs wholesalers and even retailers were involved. ${ }^{66}$ This is hardly surprising. As recent research has shown, Antwerp in the seventeenth and eighteenth centuries housed exceptionally high numbers of retailers. Apart from lace making, the retail sector appears to have been the most dynamic sector in the city after about 1650 . The number of so-called faiseurs de rien, vendeurs de tout (that is, people who make nothing but sell everything) never dropped below 1,500 members, even in the so-called 'age of crisis' (1648-1748). Around 1690, the retail ratio in Antwerp is said to have been 1 mercer for every 26 persons. In 1773 it was 1 for every 16 persons. ${ }^{67}$ Clearly, the shift towards industrial capitalism was not the only transformation the guilds had to address. We should also be attentive to mercers and retailers and their relation with guild-based producers.

Unfortunately, current research on retailing tends to focus somewhat one-sidedly (and often implicitly) on changing demand and consumer preferences, thus leaving the relationship of retail and production structures obscured. ${ }^{68}$ What if we approach the so-called retail revolution from the perspective of masters losing independence and master status becoming precarious? Were the faux-maitres in effect mercers who sold their products directly to customers? Or were they wholesalers supplying shops, perhaps shops in which other proletarianized masters (or their wives) earned their livings? An interesting path for future research would be to examine guild statutes and registration ledgers along with probate inventories and tax lists. A study that focused on Alost (a small city in south-east Flanders, on the banks of the Dender River) has revealed that crucial shifts may have occurred behind the masters' doors. The

65 See De Munck, 'Skills, trust'; and idem, Technologies, chs. 6.3 and 6.4.

66 E.g., CCA, GC 4477, 24 Jan. and 31 Mar. 1610, art. 2; GC 4477, 21 Mar. 1611, art. 2 (diamond cutters); Thijs, De zijdenijverheid, 79-83; idem, Van 'werkwinkel' tot 'fabriek', 236-43.

67 Blondé and Greefs, 'Werk aan de winkel', 207-29; L. Van Aert and I. Van Damme, 'Retail dynamics of a city in crisis. The mercer guild in pre-industrial Antwerp (c. 1648 - c. 1748)', in B. Blondé et al. (eds.), Retailers and Consumer Changes in Early Modern Europe. England, France, Italy and the Low Countries (Tours, 2005), 147-50.

68 E.g., H.-Ch. Mui and L.H. Mui, Shops and Shopkeeping in Eighteenth-Century England (London, 1989), 8-28. Additional references in I. Van Damme, 'Pendelen tussen revoluties en tradities. Recent historisch onderzoek naar de kleinhandel in de late middeleeuwen en de nieuwe tijd', Stadsgeschiedenis, 2, 1 (2007), 54-65. 
emergence of large (illicit) entrepreneurs appears to have been related to the disappearance of the 'traditional' producer-retailers who sold their own products, either directly to consumers (in their shops) or to merchants. Whereas masters were accustomed to working in the front rooms of their houses, where they were visible to both the guild deans and the customers, the emergence of shops went hand in hand with either specialization within the sector (some masters specializing in retail, others producing exclusively for large entrepreneurs) or the gradual separation of work floor and shop within the house (the work floor moving towards the back of the house). In both cases, goods sold in the shop (perhaps by the master's wife) were not necessarily made in the back (by the master) but might be supplied by a large entrepreneur, while the 'master' in the back was perhaps producing not for his or his wife's shop but for a large entrepreneur. ${ }^{69}$

Further research should of course confirm this trend (the more so as our Alost sample was rather small) but crucial questions in any case arise about the relationship between transformations in local distribution channels and the disappearance of master status. Masters who lost their independence could choose between continuing their work in the same sector, working directly for a mercer or wholesaler (either in his own house or on his employer's premises), or he could become a retailer selling products a large 'entrepreneur' had manufactured or ordered. The existing literature offers examples of masters working for wages from another master in a putting-out system while still working on their own premises. ${ }^{70}$ Others went to work on the premises of a merchant, as did the master diamond cutters with the Portuguese dealer in diamonds. As to the manufacturing of cantooren, it is hard to imagine that a cabinet was moved between workshops, so there, too, masters appear to have stopped working on their own premises. ${ }^{71}$ Other masters, although continuing to work in their own houses, may have stopped selling their own products. Some artisans, masters and others, began selling raw materials instead of concentrating on selling only finished products. While the masons (Vier gekroonden) in 1665 complained about unfree people who sold raw materials related to the building sector (stone, chalk, etc.), ${ }^{72}$ some coopers sold wooden bands ('repen') rather than using them to make barrels. ${ }^{73}$ On the other hand, finished products were gradually sold to customers by people other than producers. In 1442 the Antwerp pewterers stipulated that master pewterers could sell only their own

69 B. De Munck and R. Vermoesen, 'Shops, labour relations and distribution networks. The emergence of retail and the disappearance of producer-retailers in Alost, c. 1650 - c. 1800', paper for the Third Flemish-Dutch Conference on the Economy and Society of the Low Countries before 1850, Universiteit Antwerpen, 31 Jan. - 1 Feb. 2008.

70 E.g., Thijs, De zijdenijverheid, 77-86; Deceulaer, Pluriforme patronen, ch. 4.

${ }^{71}$ See Fabri, De 17de-eeuwse Antwerpse kunstkast. Typologische en historische aspecten, 138.

72 Prims, Geschiedenis van Antwerpen, vol. VIII, 2nd book, 89.

73 CAA, GC 4175, 26 Sep. 1580, art. 36. 
wares in stalls, ${ }^{74}$ yet during the seventeenth and eighteenth centuries this was far from straightforward. In their dispute against the mercers, the pewterers mentioned masters and masters' widows selling items they had not produced..$^{75}$ Cabinet makers, moreover, protested against masters who bought products outside the city and sold them in their 'shops' inside the city. ${ }^{76}$ The guild of locksmiths had to deal with apprentices and journeymen who moved to the countryside to make locks and other iron work that they sold in the city to 'voorkopers' (intermediaries). ${ }^{77}$

Of course, resistance to imported products was a time-honoured practice. For example, there were protests against hats made in England, France and Holland in the seventeenth century. ${ }^{78}$ There were also typical protests against unfree products from the countryside, such as by glove and purse makers in the first half of the eighteenth century. ${ }^{79}$ In these cases the distinction between guild-based products and non-guild-based products was clear. Complications ensued when either regular masters sold illicit products or illegal retailers or wholesalers sold legal products without it being clear if they had been made by masters. For the guild-based masters, production and retail - except on export markets - had to be done by one and the same person. Unfortunately for these masters, however, the straightforward bond between production and retailing - linked together by mastership - seems to have disappeared in the long run. The guild of glove and purse makers, for example, eventually allowed gloves and purses to be sold by people who had not finished an apprenticeship term or made a master piece. ${ }^{80}$ In the end, guild-based masters relinquished the visible connection between production and retail. Some gold and silversmiths even had two 'workshops' ${ }^{81}$ One guild member was fined for not displaying the guild's sign (with the typical draughtboard pattern). The master argued that he did not work there, as his furnace was in the other house, and requested permission to separate the shop from the work floor, keeping only the balance, some small instruments and some drawings in

74 Superficially this was related to the guilds' crusades against wares imported from abroad or from the countryside, but in the same ordinance it was forbidden for masters to have more than one workshop or stall, inhibiting large masters from hiring others, perhaps other masters, to sell their products. J. Van Deun, 'Het Antwerpse tinnegietersambacht in het Ancien Régime', in Keur van tin uit de havensteden Amsterdam, Antwerpen en Rotterdam (Amsterdam, 1979), 40-2.

75 CAA, GC 4265, Duplicque, art. 12.

76 CAA, GC 4334, fols. 83-5; GC 4335, 5 Nov. 1647; CAA, GC 4004, 5 Nov. 1647, fol. 9r-v; GC 4334, fols. 83-5; GC 4335, fols. 107vff. Also GC 4004, 26 Jul. 1649, fols. 24v-25r; GC 4335, 5 Mar. 1650, fol. 138v; GC 4337, fol. 30.

77 CAA, GC 4356, 29 Apr. 1603, fol. 25.

78 E.g., CAA, GC 4255, 1640.

79 E.g., CAA, GC 4259, 1 Nov. 1730.

80 CAA, GC 4259, 26 Nov. 1663.

81 Some masters among the gold and silversmiths explicitly acknowledged that they did not have a shop, but this might mean that they worked in subcontracting arrangements legally. E.g., CAA, Privilegiekamer 2560, 5th quarter, fols. 196, 209 (1747). 
the shop (which was situated in the city centre) ${ }^{82}$ These masters, in other words, not only stopped working in their homes but stopped selling their products at the production site. They had stoves and bellows elsewhere and, more importantly, they ceased to display the guilds' signs or marks. ${ }^{83}$ In short: they had relinquished the idea that the problem of product quality should be solved by tying together product quality, trade mark and master status in the front room of the masters' house - where the product was made and sold under the sign or banner of the guild.

Whenever the link between production and retail disappeared, the guilds suffered a life blow. In the previously mentioned juridical proceedings, the link between product quality and master status (the latter embodied in the obligatory apprenticeship term, the master piece and the trade mark) was the ultimate motivation for their defence against unfree work. In the end, guilds could cope with non-guild products being sold at weekly and annual markets, which were free for all sorts of products. Trademarks distinguished their products from unfree wares and allowed them to continue to claim superior quality. ${ }^{84}$ But as retail activities expanded and reached the heart of the guilds, the link between product quality and master status was severed. In the eighteenth century Paris retailers eventually began applying their own marks on silver, placing them on items made by subcontractors, thereby overruling the marks of guild-based masters. ${ }^{85}$

\section{Conclusion}

Current research tends to link the problem of illicit labour to a notion of decay, which is in turn connected to the erosion of guild rules and deregulation, especially as regards the labour market. In Antwerp, guilds did not as a rule rigorously resist the emergence of large masters. While from the start most craft guilds did not distinguish between free and unfree journeymen, rules concerning company size were gradually relaxed. Subcontracting among masters was hardly ever prohibited at all. However, regulations safeguarding master status not only continued to be applied but were developed further, particularly from the second half of the fifteenth century and well into the seventeenth century. The aim of such regulations was to prevent merchants and mercers from deploying production activities without actually being masters. Both the master piece and the requirement that apprentices board with their masters were

82 CAA, Vierschaar 1355, fol. 225. The 'shops' of gold and silversmiths were often situated in the heart of the city centre (Wisselstraat, Grote markt, etc.).

83 CAA, GC 4485, 4 Oct. 1688, fol. 33r-v (gold and silversmiths).

84 See, e.g., CAA, GC 4334, fol. 66; GC 4335, 28 Apr. 1621, art. 13 (copy). Also De Munck, 'La qualité'.

85 D. Mitchell, 'Innovation and the transfer of skill in the goldsmiths' trade in Restoration London', in D. Mitchell (ed.), Goldsmiths, Silversmiths and Bankers. Innovation and the Transfer of Skill, 1500-1800 (Stroud, 1995), 15. 
devised to prevent illicit entrepreneurs from becoming masters without having learned the trade. These regulations served the same goal as prohibitions on working in company, lending a master's trade mark to an illegal entrepreneur, and having several workshops or journeymen outside the master's premises (as these journeymen could thus be freed as well). Hence, most craft guilds repeatedly defined and redefined what licit or illicit labour (at the master level) was.

In the long run, this strategy failed. Besides the fact that the emergence of large masters heralded industrial capitalism, the Antwerp guild system was undermined by the activities of illicit entrepreneurs among whom mercers figured prominently - who took up production and circumvented mastership. Such entrepreneurs either employed journeymen or apprentices, or they turned masters into employees when they produced items that crossed guild boundaries. This may have serious implications for further research. Most unfree entrepreneurs who circumvented master status seem to have been wholesalers or even retailers, suggesting that the motivating force was not industrial capitalism but a 'retail (r)evolution', which, in turn, was related to changing consumer preferences. It would be helpful if further research examines whether the rising number of faiseurs de rien, vendeurs de tout was connected to the disappearance of the 'traditional' producer-retailer selling his own produce, either directly to customers or, in export industries, to merchants. Perhaps producer-retailers (masters) were gradually replaced by, on the one hand, proletarianized masters working for large entrepreneurswholesalers and, on the other, retailers selling produce others had delivered to them. In addition, one could ask whether former masters working for a large entrepreneur continued to work on their own premises or not. Likewise, this shift could be considered from a gender perspective. When a former producer-retailer became an employee, what changed for his wife, who was perhaps accustomed to selling her husband's products in their shop? Did she become a 'vendeuse de tout', selling products others (rather than her husband) had made?

In any case, it is important to qualify the idea that 'proletarianization' as we traditionally understand it - was the issue. Nor was the problem one of moving from a Kauf to a Verlag system. Masters, or at least their guilds, did not seem troubled by the loss of control over the means of production, being paid in raw material, or moving from a position of independent master to one of subcontractor. Rather, they were concerned with the relationship of producers to their products: above all, it had to be unambiguous who had made a product. From the guilds' perspective, problems arose only when the link between production and mastership was severed. Whether a master (or his wife) turned into a faiseur de rien, vendeur de tout or began working 'as a servant' rather than 'on his own account' (while working in his own premises in either case), the issue was that he was no longer the maker/creator of his own product. 